\title{
Research on the Establishment of Ideological and Political Education of University Students
}

\author{
Wenwen Yi and Yi Yang
}

Nanchang Key Laboratory of material and structure detection Jiangxi University of Technology

KeyWords: University Students; Ideological and Political Education; Context Construction.

\begin{abstract}
Ideological and political education of university students, as a kind of ideological education is not only the need for social development but also the need for university student growth. Therefore, ideological and political education of university students has always played an important role in university work. However, with the acceleration of social transition, a dazzling array of foreign ideas are introduced into university campus and student's values become diverse and the effectiveness of ideological and political education of college students is increasingly challenging. How to improve the actual effect of ideological and political education of university students has become a prominent practical problem. While facing such a challenging problem, the ideological and political education of university students should be implemented with a new perspective and approach as well as new channels so as to be in accordance with the requirement of cultivating talents who can be adapted to the society. This author holds the idea that the context construction of ideological and political education of college students can be regarded as the internal requirement to improve the effectiveness of ideological and political education, which should be important topics. This paper discusses the basic requirement for context construction of ideological and political education to set up standards for it.
\end{abstract}

\section{Introduction}

As a new generation of university students, they have to master abundant professional knowledge with sound personality, high quality and good behavior. No matter judging from the perspective of nation and the country or student growth, ideological and political education of university students plays an irreplaceable role. The Central Committee of the Communist Party of China has issued documents and given opinions for many times to ask universities to well implement the ideological and political education, trying unremitting efforts to strengthen the effectiveness of ideological and political education which has always been paid attention to by university education, occupying a very important role. However, in the course of implementing ideological and political education, educators always adopt traditional preaching and expository teaching which can help students to master ethical theory and moral knowledge. Yet, this kind of teaching cultivates students who think that saying and doing are two different things. However, the ultimate goal of ideological and political education of university students is to cultivate students who match word to deed. As a result, the traditional preaching and expository teaching makes the ideological and political education struggling with poor performance. How to strengthen the effectiveness of ideological and political 
education of university students and make the education become dynamic and play dual function of moral education and intellectual education have become urgent problems remained to be solved.

In ancient China, there is a case of carrying out moral education through context and Mencius' Mother Moving Three Times as well as Mencius' Mother Breaking Machine are famous examples. Even though, researches for ideological and political education started late in 1990s, China has already obtained valuable results. Monographs are: Wang Rucai The Moral Principle Education of Innovative Education, Li Hui Research on the Environment of Modern Ideological and Political Education etc which carries out discussion on the connotation, characteristics, function, idea and approach of ideological and political education. However, researches on ideological and political education are scattered without deep and systematic researches. What's more, these researches are not concrete and discussions in terms of basic steps and approaches for context construction of political and ideological education are not detailed without operability. Therefore, researches on context construction of political and ideological education remain to ve explored and developed.

This paper comprehensively adopt observation method, interview method and literature review method based on the existing research results to analyze the connotation, characteristics and function of ideological and political education of university students, and discuss its theoretical basis and practical meaning. In addition, it summarizes the basic requirement for the context construction of ideological and political education especially in the last chapter it elaborates the preparation work. Based on the above, this paper tries the utmost to innovate and develop the effectiveness of ideological and political education, aiming to make contributions to the development and construction of ideological and political education of university students.

\section{Ideological and Political Education Context Overview}

Starting from the idea of context, we can accurately have a good knowledge of the connotation of ideological and political education. So-called ideological and political education context refers to the condition that educators purposefully unify the spirit and material. In the organic unity integrating environment and feeling, university students can better know the contents and requirement of ideological and political education so as to obtain coordinated growth to form permanent excellent quality.

For a long time, in ideological and political education, various scholars confuse the ideological and political education environment with ideological and political education context, beckoning that both of them refer to the external conditions which affect ideological and political education. In fact, they are different which cannot be equated with each other. In ideological and political education activities, ideological and political education environment refers to the summation of all internal environment, including social environment, economic environment, political environment, and cultural environment which are micro and objective. In the researches carried out by previous people, some of them cannot be controlled and changed by ideological and political educators. However, ideological and political education context refers to concrete educational conditions elaborately planned by educators so as to achieve the education target which affect people's thinking and behaviors and belong to objective entities. Yet, context contains human factor, which is comparatively microscopic and subjective with operation controllability. 


\section{The theoretical basis for ideological and political education context construction of university students}

Theories without revolutionary practice are impracticable and practices without taking revolutionary theories are blind. Scientific theories are supported by practice and effective practice should be guided by revolutionary theories. Therefore, while studying on the ideological and political education context, we have to find out its theoretical original and base.

Marxist epistemology is also known as theory of knowledge of dialectical materialism which refers to the scientific theory of essence and source of thoughts as well as the development process and rules.

Judging from Marxist epistemology, human knowledge refers to the reflection on objective matters based on practice, which must take objective matters as the prototype to represent the condition, characteristics, nature and rules of objective matters with iconicity. However, it is not simple representation because in the course of reflection, there are acceptances, creative selection, analysis, application, reorganization, integration and construction, namely people choose, analyze, integrate and construct things based on existing cognitive background and mode so as to transfer subjective recognition into objective understandings. In addition, the information architecture is more important because we can assimilate information into the existing cognitive system or construct a new system based on the received information.

Marxist epistemology tells us that the process of university students accepting ideological and political education is actually a process of cognition. So in the course of context construction, we have to refer to the basic theory of Marxist epistemology so as to fully play the function of their perceptual knowledge. We should try the utmost to reflect the ideological and political education into education context so as to closely attach its contents to the objective world and real life. In specific ideological and political education context, university students can directly feel, ponder and understand it so as to take the initiative to accept it and construct correct awareness to form good behaviors.

\section{The realistic meaning for ideological and political education context construction of university students}

Our country is in a period of rapid development of market economy, and in this open society various foreign ideas and cultures are introduced into China which will affect Chinese, especially those active university students. Thus, spaces of ideological and political education in colleges and universities are being squeezed, which is under serious challenge. Although in recent years students have made a lot of explorations and attempts on its teaching approach and channel with outstanding performance. However, the teaching is still carried out based on preaching education, ignoring students' inner needs and self education, focusing on theory, rationality and teaching, ignoring practice, emotion and studying. This kind of educational approach and channel find it difficult to be adapted to the needs of modernization and cannot evoke students' moral identity. As a result, students cannot walk the talk and it is difficult to cultivate high quality talents who can be adapted to the future society. In order to fully play the leading role of ideological and political education so as to achieve effectiveness, schools have to make students as the main participants so as to expand students' educational space and establish an open and spatial educational system. The context construction of ideological and political education of university students can integrate various factors of school and society so as to form a congruent education system to effectively strengthen the overall impact of ideological and political education. 
While carrying out ideological and political education, single preaching teaching cannot help students to be engaged in it and even worse, they will feel repulsive. Nowadays, with the deepening reform and opening up, the information sources are diversified and they are strongly against the boring sermon as well as forcible preaching. Besides, they won't blindly obey educators which strengthen the difficulty of implementing ideological and political education. The context construction of ideological and political education is a breakthrough, trying to help students to take the initiative to participate in the education and make them become the organizer, guider and helper of ideological and political education. In addition, context with aesthetic feeling and emotion is in accordance with the development of university students which cannot only eliminate students' repulsive feeling but also strengthen the attractiveness of ideological and political education to generate empathy and obtain dynamic as well as positive development in terms of morality and behavior.

\section{The basic requirement for ideological and political education context construction of university students}

Context construction of ideological and political education must start from college students ' psychological characteristics and growth characteristics so as to meet their practical needs based on their cognitive structures as well as content and purpose of university students ' ideological and political education. Based on the above, the construction should be successful and effective. The following basic requirements have direct guidance effect on its successful and effective context construction.

The context construction of ideological and political education of university students is the most essential and important one and its most prominent feature is the authenticity which is reflected in various aspects and sectors in the course of its construction. The pictures, video, typical events and figures, settings and interactions between teachers and students are all real. Authenticity is the soul and essence of ideological and political education context. There are various approaches to construct the ideological and political education context which must reflect the truth. Only when the context of ideological and political education is real, can the context be dynamic and vital which can make students have immersive feelings. This kind of context can rich students' imagination and grant them with emotional as well as meaningful content in order to cultivate their good quality and improve their personality.

Relevant theories of educational psychology show that, in certain activities if participants have satisfactory and enjoyable experience, the effect shall be strengthen; in the contrast, if participants have dissatisfied and intense emotion, the effect shall be limited. Einstein once pointed out, in school and life, the most important motivation of work is pleasure of achieving results and the recognition on social value. From my perspective of view, the most important task is to inspire and strengthen young people's psychological strength. Only with such mental base, can students have pleasure and pursue the most valuable wealth that is the knowledge, art and technique. The reason for the failure of political education is that the educators adopt preaching method to imbue them with knowledge which is contrary to their pursuit for novelty, personality and interest. As a result, students won't be interested in political education and may even have irritated mood. The content of ideological and political education of university is about the truth with rich emotions. Therefore, in the course of carrying out ideological and political education, how to present the feelings and stimulate their feelings so as to ignite their interests shall be problems which are worth of thinking. In the author's 
opinion, it is a must to construct pleasing and intriguing contexts so as to make the ideological and political education be accepted by university students. Rigid contexts which only focus on thinking will never attract students so only those pleasing and relax contexts can satisfy students who expect to pursue novelty and fun. When students are engaged in such pleasant and relaxed context they will no longer be depressed or bored. They will take the initiative to participate in the education and feel relaxed which can stimulate their happy experience and easily accept the ideological and political education.

University students ' ideological and political education context has good interactive ability as well as coordination function. In this context, educators can communicate with students in terms of psychology so as to exchange their feelings. However, the traditional education model which has been implemented for a long time makes a condition that students feel inferior. Educators tend to adopt indifferent manner and the relationship between teachers and students is not harmonious. If educators are not willing to change their profile and don't take the initiative to communicate with students, the interactive ability as well as the coordination ability will be greatly damaged and an ineffective education context is then established. Therefore, educators should change their attitude toward students, cultivate passionate meticulous and sincere quality and treat students like friends so as to eliminate their prejudice and even hostile emotions toward teachers. What's more, students and teachers will trust each other with a harmonious relationship. The harmonious relationship can help to better play the inactive and coordination ability and then the communication between students and teachers shall become frequent. Based on this, students shall be interested in receiving education and the effect of ideological and political education will be better to finally achieve the condition that teaching benefits teachers as well as students.

\section{Conclusions}

Ideological and political education of university students carries the important mission to cultivate their morality and change their moral life. However, their personalities become obvious and the society is becoming open which bring lots of challenges and difficulties for the ideological and political education. Facing difficulties and challenges, domestic educators and scholars have carried out various researches in order to strengthen its effectiveness. I also hope that my study can help to enhance its effectiveness. After studying for more than one year, I realize that the moral ethics learning, pondering and practice all need education context. The first step to better play the function of ideological and political education is to conduct context construction which is a key step and directly affect the ideological and political education performance. Because of limited knowledge and abilities, this paper is not deep and maybe with shortcomings. The basic steps to construct ideological and political education context and the elaboration to regulate the construction are not explained perfectly. At present, sky rocketing experts, scholars and educators recognize and accept the context construction of ideological and political education. I believe that it will receive more and more attention by scholars and experts with deep exploration. In the near future, relevant researches will achieve breakthroughs with fruitful results. 


\section{Acknowledgment}

This work was supported by Project on professional and characteristical construction of Jiangxi province 2010 (Civil Engineering) and Project on the planning and construction of disciplines in Jiangxi University of Technology (Structure Engineering)

\section{References}

[1] Xia Zhengnong. Dictionary [M]. Shanghai: Shanghai Lexicographical Publishing House, 1989: 389.

[2]Yang Qingzhu. Concise Psychology Dictionary[M]. Shenyang: Jilin People's Publishing House1985: 307.

[3]Sha Lianxiang. Social Psychology [M]. Beijing: China Renmin University Press, 1987: 49-50.

[4] Xiaochuan. Characteristics of Education Context[N]. China Education Daily, 2002.2.26.

[5] Wang Wanming, Wei Kenan. Basic Theory of Marxism[M]. Chengdu: Sichuan People's Publishing House, 2001: 107.

[6]Basic Principles of Marxism[M]. Beijing: Higher Education Press. 2007: 58.

[7].Li Hui. Research on Modern Ideological and Political Education Environment[M]. Guangzhou: Guangdong People's Publishing House, 2005: 253-260.

[8] Li Qingming. Li Jilin and Context Education [M]. Beijing: International Cultural Publishing House, 2003: 53.

[9] Lu Jie Wang Fengxian. New Opinions on Moral Education[M]. Nanjing: Jiangsu Education Publishing House, 1994: 323.

[10] Suhomlinski. Suggestions for Teachers [M]. Beijing: Educational Science Publishing House, 1984: 58 . 